\title{
A longitudinal study on how informal science learning is applied in generic learning outcomes (GLO)
}

\author{
Ig-Hyeng Cho, Doctoral Student, Dept. Of Knowledge Service \& Consulting, Hansung University, 028 \\ 76, Seoul, Korea, Cho-ig@hansung.ac.kr \\ Yen-Yoo You, Professor, Dept. Of Knowledge Service \& Consulting, Hansung University, 02876, Seoul, \\ Korea, threey0818@hansung.ac.kr \\ *Kwan-Sik Na, Professor, Seowon University, 28674, Chungcheongbukdo, Korea, ksna@seowon.ac.kr \\ *Corresponding author
}

\begin{abstract}
Education in the informal educational environment is very important in terms of be ing able to provide essential knowledge that formal education cannot provide. But the reality is that there is no research on how the study of ISL has been done from the past to the present. Thus, this paper seeks to compare and analyze the recent research trends of paper $\mathrm{s}$ relating to ISL published within a specific timeframe. The target research papers for analysi $\mathrm{s}$ are based on ISL-related academic dissertations, articles and research reports, which were 1 ocated via Google and Google Scholar, within the period of 2010 to 2019. Each research pap er was classified into 8 indicators: 'Paper Type', 'ISL Type', 'Research Design', 'Subject of stud y', 'GLO Type' and 'Country', which were then analyzed accordingly and tested for suitability through 'Chi-Square Test'. The study of ISL was led by the United States and the United Kin gdom and there was no significant difference by year. Most of the research samples tended $t$ o converge towards 'Empirical research articles' and 'Position papers', with studies on ISL als o mostly containing information related to advice, recommendation and support. It was found that the researchers were using ISL in order to pursue 'Knowledge and Understanding' and 'Attitudes and Values', of the 5 indicators of the 'GLO'. In contrast, they were found to have the least expectations for 'Skills' and 'Enjoyment, Inspiration and Creativity', suggesting the $n$ eed for future improvement in these areas. Although this paper suffers from limitation with $r$ egards to time period as it focuses on research work published from 2010 to 2019, it attem pts to suggest a direction for program development and research for various educational prac titioners working in 'ISL'. Also, it hopes to provide a good opportunity for institutions using 'ISL' in the field, as well as teachers and future researchers.
\end{abstract}

Keywords: Education, Informal science learning, Out-of-school, Non-formal, GLO.

Received: 17.12.2020 $\quad$ Accepted: 05.01.2021 $\quad$ Published: 02.02.2021

\section{INTRODUCTION}

Dewey argues that education must be based on experience. Experience here refers to an actual experience that an individual has encountered in one's real life [1]. Everyday life experiences outside the school setting have significant influence on school life and kids' achievements [2]. Although many researchers define experiences outside school settings with various terms such as 'Informal Education', 'Non-formal Education', and 'Out-of-school Education', there is a continuous disharmony and confusion regarding term usage $[3,22]$. Non-formal Education refers to an organized, systematic and educational activity that takes place outside the framework of an official system [4]. In this case, the study motivation, although influenced by (formal) education, rests entirely upon the learner [3]. Informal Education is a life process whereby an individual acquires and accumulates knowledge, skills, attitudes and insight from everyday life experience and exposure. These activities could take place while at home or at the workplace, while playing, from family and friends, while travelling, reading newspapers or books, listening to the radio, or watching movies and television [4]. Recently, the traditional Informal Education Environment has been spreading to new spaces, such as social media, websites and on-line communities [5]. Informal Education is distinguished from Non-formal Education and (Formal) Education in that the former involves no authoritative figure (authority) or an arbitrator (arbitral institution), while it is identical to Non-formal Education in that the learner has a learning motivation [3]. 
The diverse experiences outside the school environment are being used in various ways, especially in the sciences [6]. Students in ordinary, voluntary, and unstructured spaces apart from schools and a variety of other contexts [7], are able to appreciate greater inquiry, joy and satisfaction from an informal science learning experience [8]. Science-related learning that takes place in such informal and out-of-school contexts [9] is usually called 'Informal Science Learning (ISL)'. ISL activities encompass a wide variety of activities, such as participating in exhibits and programs provided in science museum visits, science camps and events, extracurricular programming, and science lectures [6,9], healthcare [2339]. Through ISL education, students learn to think, act and communicate as members of a community to solve a given problem [7]. However, ISL is difficult to evaluate. Discussions about how to best assess the methods of ISL have been ongoing, with various solutions being studied. The Research Centre for Museums and Galleries (RCMG) developed a method to measure the effects of learning in museums and libraries, which is known as 'Generic Learning Outcomes' (GLO) [10]. Visitors to informal education institutes, such as museums, learn about one of the five topics shown in Table 1, which can be used to predict the learning outcome of an activity, set follow-up research questions, and provide an evaluation framework to analyze the visitors' experiences [11]. The GLO is not a normative framework, so it can be used flexibly to facilitate discussions, analysis and data collection [10].

Table 1 GLO (Generic Learning Outcomes)

$\begin{array}{ll}\checkmark & \text { Knowledge and Understanding } \\ \checkmark & \text { Skills } \\ \checkmark & \text { Attitudes and Values } \\ \checkmark & \text { Enjoyment, Inspiration and Creativity } \\ \checkmark & \text { Activity, Behavior and Progression }\end{array}$

Although many studies related to ISL are in progress, there is a dearth of trend analysis in these studies. Thus, this study attempts to classify recent papers on ISL and other research works with an objective indicator, and conduct a comparative analysis with each GLO element, to inspire future researchers. It could be an especially useful guide for teachers and science education program designers who wish to join ISL with the general curriculum.

\section{Materials and methods}

\subsection{Research target}

The research samples are based on academic dissertations, scholarly articles and research reports, which were located via Google and Google Scholar, within the period of 2010-2019. Search keywords were 'informal', 'non-formal', 'out-of-school', 'education', 'science camp', 'science event', and 'museum', with each keyword made searchable with the word 'informal science learning' included, with the use of Google operator. However, since papers located in this manner amounted to a few hundred papers and were thus difficult to analyze in a short time, we reselected the papers so that the contents of each paper included the keyword 'informal science learning'. Out of those selected, papers with the keyword 'informal science learning' appearing only in the 'reference' and papers that are difficult to evaluate GLO were also eliminated. Through this process, the final samples numbered 29 papers, which were categorized and analyzed according to each criterion (Refer to the following link for the list of sample work: https://1drv.ms/x/s!AspakG4TJsqCkQpw8QfZ1H1em3ab?e=Khjmqg).

\subsection{Research method}

Each of the papers and research works selected as samples were classified according to eight indicators and analyzed accordingly: 'Paper Type', 'ISL Type', 'Research Design', 'Subject of study', 'GLO Type', 'Country', and 'Year'. 'Paper Type' is an indicator that classifies the types of research works. Subcategories have been classified as either 'Empirical research article', 'Position paper', 'Theoretical paper', 'Review', or 'Others', in reference to Smith (1998) and Tsai (2005)'s works [12, 13].

The 'ISL Type' indicator was further classified into 'Content' and 'Style', with specific sub-categories designated. 'Content' seeks to identify which ISL activities the researcher(s) focused on in their paper. Sub-categories were classified as 'Experiment', 'Show or demonstration', 'Hands-on exhibits', 'Games', 'Field trips', 'Science events', and 'Others', with reference to 'Triyarat (2017)' and 'Hromek \& Roffey (2009)' work $[14,21]$. 'Style' seeks to identify the locations in which the ISL studies took place. Sub-categories were classified into 'Institutional Portal (Museums, Science Centers, Zoos, Libraries, Other institutional 
portal)', 'Social Interaction', 'Text-based', 'All (Institutional Portal)', and 'Others', with reference to the works of Crane (1994), Fenichel (2010) and Walsh (2014) [6, 15, 16]. Since it was expected that researchers would tend to group multiple venues in which ISL is implemented, rather than conducting studies in the same venue, there was a need for a more detailed classification within the specific subcategories. We designated a sub-category for the 'Institutional Portal' category, for which significant research is being done, while combining 'social interaction (Friends, Experts, Family, Colleague, Seminars, Lectures, Conferences, etc...)' and 'text-based (Internet, Books, Journals, Magazine, Newspaper, Articles, Blogs, etc...) - which are expected to be subject to relatively fewer studies - into a single category.

'Research Design' identifies a data collection method for a given dataset, whose category was decided without distinguishing between qualitative and quantitative research. Sub-categories were classified into 'Surveys', 'Assessments/Tests', 'Interviews', 'Focus groups', 'Observation', 'Document Review', 'Tracking', 'Participation', and 'Others', with the use of the work of Fountain (2010) and Creswell (2017) and other resources $[17,18]$.

'Subject of study' is an indicator that classifies the study targets. Because it was difficult to find prior studies for classification into sub-categories, we examined all sample papers and classified arbitrarily as follows: 'Infants/Kindergarteners', 'Elementary school students', 'Middle school students', 'High school students', 'Undergraduates (Post-graduates)', 'School parents', 'General visitors', 'Institution personnel (employees)', 'Program designers', '(Preservice) Teachers', 'Relations experts', and 'Others'.

'GLO Type' was classified after the contents of each paper were analyzed and compared with each 'GLO' category. Ambiguous information was classified into the nearest possible category, while papers with no discernable relevance were classified as 'Others'. Sub-categories were classified into 'Knowledge and Understanding', 'Skills', 'Attitudes and Values', 'Enjoyment, Inspiration and Creativity', 'Activity, Behavior and Progression', and 'Others', with reference to Hooper-Greenhill (2003, 2007), Gibbs (2007) and Bollo (2013)'s studies [10,11, 19, 20].

'Country' was classified according to the home countries of the universities and academic journals where papers were published, after all the sample papers were examined. If the author's nationality was different from the country where the institution or university was located, the institution and university were used as the basis for classification. If a study was conducted in more than two institutions and universities in different countries, both countries were designated as classification categories.

'Year' is an indicator used in order to classify the publication year of the sample papers. It is based on papers published from 2010-2019, as mentioned in the 'Research sample' sub-section.

\section{Results}

Each sample research work was classified according to the research method mentioned above, with multiple categories selected a number of times, or a particular category remaining empty, depending on the contents. For example, when we identified the 'Research Design' indicator in one sample paper, we classified it according to each category when multiple methods were used for data collection categories, such as 'Surveys', 'Interviews', and 'Focus groups', even if it only involved a single paper. Thus, it is possible that the numbers that appear in categories for each indicator may be greater than the sample paper size. In other words, there are 29 samples, but this number could be displayed as either greater or smaller, according to each indicator. Contents are classified according to each indicator as follows.

Examination of the 'Paper Type' of sample research works revealed that 'Empirical research article' papers, which are based on empirical studies such as academic dissertation and scholarly articles, were the most numerous. Next in the list was 'Position paper', which are like research reports that objectively explain ISL. These two categories held numerical dominance, comprising $79 \%$ of all sample papers. Upon examination of paper publication numbers by year, it can be seen that the volume of research decreased in 2013 and 2014, before increasing from 2015 onwards, as shown in Table 2.

Table 2 Paper Type

\begin{tabular}{|c|c|c|c|c|c|c|c|c|c|c|c|}
\hline ear $\mathrm{Y}$ & $\begin{array}{l}201 \\
0\end{array}$ & $\begin{array}{l}201 \\
1\end{array}$ & $\begin{array}{l}201 \\
2\end{array}$ & $\begin{array}{l}201 \\
3\end{array}$ & $\begin{array}{l}201 \\
4\end{array}$ & $\begin{array}{l}201 \\
5\end{array}$ & $\begin{array}{l}201 \\
6\end{array}$ & $\begin{array}{l}201 \\
7\end{array}$ & $\begin{array}{l}201 \\
8\end{array}$ & $\begin{array}{l}201 \\
9\end{array}$ & \\
\hline Paper Type & 2 & 3 & 3 & 1 & 1 & 5 & 2 & 3 & 4 & 5 & 29 \\
\hline $\begin{array}{ll}\begin{array}{l}\text { Empirical } \\
\text { article }\end{array} & \text { research } \\
\end{array}$ & & & 2 & 1 & & 3 & 1 & 1 & 3 & 3 & 14 \\
\hline Position paper & 2 & 1 & & & & 2 & 1 & & 1 & 2 & 9 \\
\hline Theoretical paper & & & & & 1 & & & 1 & & & 2 \\
\hline Review & & 2 & 1 & & & & & 1 & & & 4 \\
\hline
\end{tabular}


An examination of the 'Content' aspect of 'ISL Type' revealed multiple papers for which the 'ISL Type' could not be determined. Also, it can be seen that the numbers are concentrated in the 'Others' category [Table 3]. This result is likely because researchers mostly conducted studies on visitors to institutions participating in ISL-related activities, participation and support for the local community, and policy aspects (rather than focusing their research on specific activities). In the 'style' aspect, it can be seen that significant research has been conducted on 'All (Institutional Portal)', 'text-based', and 'Others' categories. The 'All (Institutional Portal)' category shows that active research has been conducted not only on specific ISL institutions, but also on institutions as a whole. Table 4 shows that there has generally been steady research input into the 'text-based' category which uses the Internet, Newspaper and Blogs, while there has been a noticeable increase in the 'Others' category since 2015 , with a surge in studies that use various media.

Table 3 ISL Type (Content)

\begin{tabular}{|c|c|c|c|c|c|c|c|c|c|c|c|}
\hline ear & $\begin{array}{l}201 \\
0\end{array}$ & $\begin{array}{l}201 \\
1 \\
\end{array}$ & $\begin{array}{l}201 \\
2 \\
\end{array}$ & $\begin{array}{l}201 \\
3\end{array}$ & $\begin{array}{l}201 \\
4 \\
\end{array}$ & $\begin{array}{l}201 \\
5 \\
\end{array}$ & $\begin{array}{l}201 \\
6\end{array}$ & 2017 & $\begin{array}{l}201 \\
8\end{array}$ & $\begin{array}{l}201 \\
9\end{array}$ & \\
\hline ISL Type & 2 & 2 & 4 & 1 & 0 & 4 & 2 & 4 & 4 & 6 & 29 \\
\hline Experiment & & & & 1 & & & 1 & & & 1 & 3 \\
\hline Show or demonstration & & & & & & 1 & & 1 & & & 2 \\
\hline Hands-on exhibits & & & & & & 1 & & & & 1 & 2 \\
\hline Games & & & & & & & & & & & 0 \\
\hline Field trips & 1 & & 2 & & & & & 1 & & 1 & 5 \\
\hline Science events & & & 1 & & & 1 & 1 & 1 & 1 & 1 & 6 \\
\hline 'Others & 1 & 2 & 1 & & & 1 & & 1 & 3 & 2 & 11 \\
\hline
\end{tabular}

Table 4 ISL Type (Style)

\begin{tabular}{|c|c|c|c|c|c|c|c|c|c|c|c|c|}
\hline \multirow{2}{*}{\multicolumn{2}{|c|}{ ear }} & $\begin{array}{l}201 \\
0\end{array}$ & $\begin{array}{l}201 \\
1\end{array}$ & $\begin{array}{l}201 \\
2\end{array}$ & $\begin{array}{l}201 \\
3\end{array}$ & $\begin{array}{l}201 \\
4\end{array}$ & $\begin{array}{l}201 \\
5\end{array}$ & $\begin{array}{l}201 \\
6\end{array}$ & $\begin{array}{l}201 \\
7\end{array}$ & $\begin{array}{l}201 \\
8\end{array}$ & $\begin{array}{l}201 \\
9\end{array}$ & \\
\hline & & 3 & 3 & 6 & 1 & 0 & 5 & 1 & 5 & 5 & 7 & 36 \\
\hline \multirow{5}{*}{$\begin{array}{l}\text { Institution } \\
\text { al portal }\end{array}$} & Museums & & & & & & 1 & & & 1 & & 2 \\
\hline & $\begin{array}{l}\text { Science } \\
\text { centers }\end{array}$ & & 3 & 1 & & & & & & & 1 & 5 \\
\hline & $\begin{array}{l}\text { Zoos } \\
\text { (Aquariums) }\end{array}$ & & & & & & & & & & & 0 \\
\hline & Libraries & & & & & & 2 & & & & & 2 \\
\hline & $\begin{array}{l}\text { Other } \\
\text { institutional } \\
\text { portal }\end{array}$ & 1 & & 1 & & & & & & 1 & 2 & 5 \\
\hline \multicolumn{2}{|c|}{ All (Institutional portal) } & 1 & & 1 & & & & & 1 & 2 & 2 & 7 \\
\hline \multicolumn{2}{|c|}{$\begin{array}{l}\text { Social interaction } \\
\text { (Friends, Experts, Family } \\
\text { etc) }\end{array}$} & & & 1 & & & & & 1 & & & 2 \\
\hline \multicolumn{2}{|c|}{$\begin{array}{l}\text { Text-based } \\
\text { (Internet, Newspaper, } \\
\text { Blogs etc) }\end{array}$} & & & 1 & 1 & & & & 1 & & & 3 \\
\hline \multicolumn{2}{|c|}{$\begin{array}{l}\text { Others (Television, Radio } \\
\text { etc) }\end{array}$} & 1 & & 1 & & & 2 & 1 & 2 & 1 & 2 & 10 \\
\hline
\end{tabular}

An examination of the 'Research Design' indicator revealed that two categories - 'Surveys' and 'Interviews', had the overwhelming majority of the data collection methods, as shown in Table 5. 
Table 5 Research Design

\begin{tabular}{|l|l|l|l|l|l|l|l|l|l|}
\hline $\begin{array}{l}\text { Researc } \\
\text { h } \\
\text { Designs }\end{array}$ & $\begin{array}{l}\text { Surve } \\
\text { ys }\end{array}$ & $\begin{array}{l}\text { Assessm } \\
\text { ents/ } \\
\text { Tests }\end{array}$ & $\begin{array}{l}\text { Intervi } \\
\text { ews }\end{array}$ & $\begin{array}{l}\text { Focu } \\
\text { s } \\
\text { grou } \\
\text { ps }\end{array}$ & $\begin{array}{l}\text { Observat } \\
\text { ion }\end{array}$ & $\begin{array}{l}\text { Docum } \\
\text { ent } \\
\text { review }\end{array}$ & $\begin{array}{l}\text { Tracki } \\
\text { ng }\end{array}$ & $\begin{array}{l}\text { Participati } \\
\text { on } \\
\text { (Worksho } \\
\text { p etc) }\end{array}$ & $\begin{array}{l}\text { Other } \\
\text { s }\end{array}$ \\
\cline { 2 - 11 } & 16 & 2 & 12 & 4 & 5 & 5 & 0 & 4 & 6 \\
\hline
\end{tabular}

Upon examination of the 'Subject of study' indicator that allows us to look at the research targets, it can be seen that a significant number of studies targeted elementary and middle school students, while the 'Relations expert', 'Institution personnel (employee)' and 'Teacher' categories also comprised a high proportion. The proportion of relations experts was high because of the large number of studies aimed at providing advice, recommendations, support and data development to such experts. Table 6 shows that 'Position papers', which made up a high proportion of the 'Paper Type' indicator, mostly contain this type of information.

Table 6 Subject of study

\begin{tabular}{|c|c|c|c|c|c|c|c|c|c|c|c|c|}
\hline \multirow[t]{2}{*}{$\begin{array}{l}\text { Subje } \\
\text { ct of } \\
\text { study }\end{array}$} & $\begin{array}{l}\text { Infa } \\
\text { nt/ } \\
\text { Kind } \\
\text { erga } \\
\text { rten } \\
\text { er }\end{array}$ & $\begin{array}{l}\text { Ele } \\
\text { men } \\
\text { tary } \\
\text { scho } \\
\text { ol } \\
\text { stud } \\
\text { ent }\end{array}$ & $\begin{array}{l}\text { Mid } \\
\text { dle } \\
\text { scho } \\
\text { ol } \\
\text { stud } \\
\text { ent }\end{array}$ & $\begin{array}{l}\text { High } \\
\text { scho } \\
\text { ol } \\
\text { stud } \\
\text { ent }\end{array}$ & $\begin{array}{l}\text { Under } \\
\text { gradu } \\
\text { ate } \\
\text { (Post- } \\
\text { gradu } \\
\text { ate) }\end{array}$ & $\begin{array}{l}\text { Scho } \\
\text { ol } \\
\text { pare } \\
\text { nt }\end{array}$ & $\begin{array}{l}\text { Gen } \\
\text { eral } \\
\text { visi } \\
\text { tor }\end{array}$ & $\begin{array}{l}\text { Institut } \\
\text { ion } \\
\text { person } \\
\text { nel } \\
\text { (emplo } \\
\text { yee) }\end{array}$ & $\begin{array}{l}\text { Pro } \\
\text { gra } \\
\mathrm{m} \\
\text { desi } \\
\text { gne } \\
\mathrm{r}\end{array}$ & $\begin{array}{l}\text { (Pre- } \\
\text { servi } \\
\text { ce) } \\
\text { teach } \\
\text { er }\end{array}$ & $\begin{array}{l}\text { Rel } \\
\text { atio } \\
\text { ns } \\
\text { exp } \\
\text { ert }\end{array}$ & $\begin{array}{l}\text { Othe } \\
\text { rs }\end{array}$ \\
\hline & 1 & 10 & 9 & 2 & 2 & 5 & 1 & 5 & 3 & 6 & 7 & 5 \\
\hline
\end{tabular}

For the 'GLO Type' indicator, we confirmed the study purpose and conclusion of sample papers and compared them with each 'GLO' category. In general, researchers conducted a significant number of studies on 'Knowledge and Understanding' and 'Attitudes and Values', while conducting relatively fewer studies on 'Skills' and 'Enjoyment, Inspiration and Creativity' categories. Upon analysis by year, it can be seen that there has been a significant rise in studies on the 'Activity, Behavior and Progression' category since 2015. The proportion of the 'Others' category is high, because apart from the 'GLO' category, most sample papers also contain information related to advice, recommendations, and support and data development, while there was almost no information on 'GLO' in some sample papers, as Table 7 illustrates.

Table 7 GLO Type

\begin{tabular}{|c|c|c|c|c|c|c|c|c|c|c|c|}
\hline ear & $\begin{array}{l}201 \\
0 \\
\end{array}$ & $\begin{array}{l}201 \\
1 \\
\end{array}$ & $\begin{array}{l}201 \\
2 \\
\end{array}$ & $\begin{array}{l}201 \\
3 \\
\end{array}$ & $\begin{array}{l}201 \\
4 \\
\end{array}$ & $\begin{array}{l}201 \\
5 \\
\end{array}$ & $\begin{array}{l}201 \\
6 \\
\end{array}$ & $\begin{array}{l}201 \\
7 \\
\end{array}$ & $\begin{array}{l}201 \\
8\end{array}$ & $\begin{array}{l}201 \\
9 \\
\end{array}$ & \\
\hline GLO & 4 & 9 & 6 & 1 & 2 & 12 & 5 & 4 & 6 & 11 & 60 \\
\hline $\begin{array}{ll}\text { Knowledge } & \text { and } \\
\text { Understanding } & \end{array}$ & 1 & 2 & 2 & & 1 & 3 & & & 1 & 1 & 11 \\
\hline Skills & & 2 & & & 1 & 3 & & & & 2 & 8 \\
\hline Attitudes and Values & & 2 & 3 & 1 & & 4 & 2 & & 3 & 3 & 18 \\
\hline $\begin{array}{l}\text { Enjoyment, Inspiration and } \\
\text { Creativity }\end{array}$ & 1 & & & & & 1 & 1 & 1 & & 1 & 5 \\
\hline $\begin{array}{l}\text { Activity, Behavior and } \\
\text { Progression }\end{array}$ & 2 & 1 & & & & 1 & 1 & 3 & 1 & 3 & 12 \\
\hline Others & & 2 & 1 & & & & 1 & & 1 & 1 & 6 \\
\hline
\end{tabular}

'Country' indicator allows us to look at the countries in which the sample papers were published. The United States published the largest number of papers, with a noticeable difference in contrast to the other countries. It is also interesting to note that papers were published steadily from 2010 to 2019. The United Kingdom has also contributed many studies, with an increase in the number of studies since 2015. Studies 
in other countries started after 2014 [Table 8].

Table 8 Country

\begin{tabular}{|c|c|c|c|c|c|c|c|c|c|c|c|}
\hline ear $\mathrm{Y}$ & $\begin{array}{l}201 \\
0\end{array}$ & $\begin{array}{l}201 \\
1\end{array}$ & $\begin{array}{l}201 \\
2\end{array}$ & $\begin{array}{l}201 \\
3\end{array}$ & $\begin{array}{l}201 \\
4\end{array}$ & $\begin{array}{l}201 \\
5\end{array}$ & $\begin{array}{l}201 \\
6\end{array}$ & $\begin{array}{l}201 \\
7\end{array}$ & $\begin{array}{l}201 \\
8\end{array}$ & $\begin{array}{l}201 \\
9\end{array}$ & \\
\hline Paper Type & 2 & 3 & 3 & 1 & 1 & 5 & 2 & 3 & 5 & 5 & 29 \\
\hline United States & 2 & 2 & 2 & 1 & & 3 & & 2 & 2 & 3 & 17 \\
\hline United Kingdom & & 1 & 1 & & & 1 & 1 & 1 & & & 5 \\
\hline Japan & & & & & & & & & 1 & & 1 \\
\hline Switzerland & & & & & & & 1 & & & & 1 \\
\hline Greece & & & & & 1 & & & & & & 1 \\
\hline Hungary & & & & & & & & & 1 & & 1 \\
\hline Saudi Arabia & & & & & & 1 & & & & & 1 \\
\hline Malta & & & & & & & & & & 1 & 1 \\
\hline Turkey & & & & & & & & & & 1 & 1 \\
\hline
\end{tabular}

\section{Empirical Analysis}

The data presented in the above results were checked for suitability for each part. SPSS was used and the suitability test was conducted through 'Chi-Square'.

As a result of conducting the suitability test for the 'GLO Type' indicator, it was found that ChiSquare $=11.400, \rho=.044$ [Table 9]. This shows that the observed values are statistically significant and there is a difference between the items. This shows that the classification through 'GLO' is meaningful in this study as in the previous study [19], which confirmed that 'GLO' can be used as a general category to measure the range of learning results.

Table 9 GLO Type

\begin{tabular}{|l|l|l|l|}
\hline GLO & Observed N & Expected N & Residual \\
\hline $\begin{array}{l}\text { Knowledge and } \\
\text { Understanding }\end{array}$ & 11 & 10.0 & 1.0 \\
\hline Skills & 8 & 10.0 & -2.0 \\
\hline Attitudes and Values & 18 & 10.0 & 8.0 \\
\hline $\begin{array}{l}\text { Enjoyment, Inspiration } \\
\text { and Creativity }\end{array}$ & 5 & 10.0 & -5.0 \\
\hline $\begin{array}{l}\text { Activity, Behavior and } \\
\text { Progression }\end{array}$ & 12 & 10.0 & 2.0 \\
\hline Others & 6 & 10.0 & -4.0 \\
\hline Total & 60 & & \\
\hline
\end{tabular}

\begin{tabular}{|l|l|}
\hline & GLO \\
\hline Chi-Square & $11.400^{a}$ \\
\hline df & 5 \\
\hline Asymp. Sig. & .044 \\
\hline $\begin{array}{l}\text { a. } 0 \text { cells (0.0\%) have } \\
\text { expected frequencies } \\
\text { less than 5. The } \\
\text { minimum expected cell } \\
\text { frequency is } 10.0\end{array}$ \\
\hline
\end{tabular}

In the 'Country' indicator, the countries in which the sample papers were published were classified into nine countries, but the observations were measured insignificantly. Therefore, through 'Google Trend', we searched for the most important keywords in this paper, 'Informal science learning', 'Out of school', 'Science event', and 'Science camp'. As a result, among the nine countries searched in the sample paper, the United States and the United Kingdom were found in the largest proportion, and other countries were not. Based on this, the United States and the UK, which published the most studies, were classified as separate items, and the rest of the countries were classified as one item. As a result, Chi-Square $=8.552$, $\rho=.014$ was shown [Table 10], and it can be confirmed that the observed value is statistically significant.

Table 10 Country

\begin{tabular}{|l|l|l|l|}
\hline Country & Observed N & Expected N & Residual \\
\hline United States & 17 & 9.7 & 7.3 \\
\hline United Kingdom & 5 & 9.7 & -4.7 \\
\hline Others & 7 & 9.7 & -2.7 \\
\hline Total & 29 & & \\
\hline
\end{tabular}

\begin{tabular}{|l|l|}
\hline & Country \\
\hline Chi-Square & $8.552^{\mathrm{a}}$ \\
\hline df & 2 \\
\hline Asymp. Sig. & .014 \\
\hline a. 0 cells $(0.0 \%)$ have \\
\hline
\end{tabular}


The 'Paper Type' indicator also showed Chi-Square=11.966, $\rho=.008$ [Table 11] and it can be confirmed that the observed values are statistically significant. It can be seen that the same results as the previous studies [12] showed that the thesis classification reflects original and empirical research, and that 'Empirical research articles' account for the largest number.

Table 11 Paper Type

\begin{tabular}{|l|l|l|l|}
\hline Paper Type & Observed N & Expected N & Residual \\
\hline $\begin{array}{l}\text { Empirical research } \\
\text { article }\end{array}$ & 14 & 7.3 & 6.8 \\
\hline Position paper & 9 & 7.3 & 1.8 \\
\hline Theoretical paper & 2 & 7.3 & -5.3 \\
\hline Review & 4 & 7.3 & -3.3 \\
\hline Total & 29 & & \\
\hline
\end{tabular}

\begin{tabular}{|l|l|}
\hline & $\begin{array}{l}\text { Paper } \\
\text { Type }\end{array}$ \\
\hline $\begin{array}{l}\text { Chi- } \\
\text { Square }\end{array}$ & $11.966^{\mathrm{a}}$ \\
\hline $\mathrm{df}$ & 3 \\
\hline $\begin{array}{l}\text { Asymp. } \\
\text { Sig. }\end{array}$ & .008 \\
\hline $\begin{array}{l}\text { a. 0 cells }(0.0 \%) \text { have } \\
\text { expected frequencies } \\
\text { less than 5. The } \\
\text { minimum expected cell } \\
\text { frequency is 7.3 }\end{array}$ \\
\hline
\end{tabular}

The 'Subject of Study' indicator, which can identify the subjects of the study, was divided into a total of 12 categories, including elementary school students, middle school students, parents, and related experts, but the observations were not statistically significant. Therefore, items from 'Infant/Kindergartener' to 'Undergraduate (Post-graduate)', 'School parent' and '(Pre-service) teacher' items were integrated and tested by integrating 'persons involved in education', 'Institution personnel (employee)', 'Program designer' and 'relationship experts' into 'experts', 'general visitors' and finally 'other' categories. As a result, it was shown Chi-Square $=49.429, \rho=.000$ [Table 12] and it can be confirmed that the observed value is statistically significant.

Table 12 Subject of study

\begin{tabular}{|l|l|l|l|}
\hline Subject of study & $\begin{array}{l}\text { Observed } \\
\mathrm{N}\end{array}$ & $\begin{array}{l}\text { Expected } \\
\mathrm{N}\end{array}$ & Residual \\
\hline $\begin{array}{l}\text { persons involved in } \\
\text { education }\end{array}$ & 35 & 14.0 & 21.0 \\
\hline $\begin{array}{l}\text { General visitor } \\
\text { Relations expert }\end{array}$ & 15 & 14.0 & -13.0 \\
\hline Others & 5 & 14.0 & 1.0 \\
\hline & & 14.0 & -9.0 \\
\hline Total & 56 & & \\
\hline
\end{tabular}

\begin{tabular}{|l|l|}
\hline & $\begin{array}{l}\text { Subject of } \\
\text { study }\end{array}$ \\
\hline $\begin{array}{l}\text { Chi- } \\
\text { Square }\end{array}$ & 49.429 a \\
\hline df & 3 \\
\hline $\begin{array}{l}\text { Asymp. } \\
\text { Sig. }\end{array}$ & .000 \\
\hline $\begin{array}{l}\text { a. } 0 \text { cells }(0.0 \%) \text { have } \\
\text { expected frequencies less } \\
\text { than 5. The minimum } \\
\text { expected cell frequency is } \\
14.0 .\end{array}$ \\
\hline
\end{tabular}

The 'content' index of 'ISL Type' was found to be not statistically significant. The asymptotic significance probability (Asymp. Sig.) was significant as .033, but cells with an expected frequency of less than 5 were measured as $100 \%$. [Table 13] Since it is difficult to adjust the items for the 'content' indicator, it was concluded that this part was not significant. Most of the previous studies [14], which were the criteria for classification, classified factors centering on science centers and museums. However, as can be seen by checking the 'ISL Type (Style)' part of the analysis papers, in addition to the 'Institutional Portal' where science centers and museums dominate, various informal science learning sites are being studied. This can be seen even if you see the most 'Others' part of 'ISL Type (Content)'. It seems that the classification indicator for this part should be studied in the future. Rather than direct experiments with students, there were many papers that observed non-formal science education through observations, 
interviews and questionnaires for guardians such as teachers and parents. It is recommended to update the classification later.

The 'type' indicator part was measured as 'Chi-Square $=13.722$ ' and ' $\rho=.008$ ', indicating that the observed value is statistically significant. [Table 14]

Table 13 ISL Type (Content)

\begin{tabular}{|l|l|l|l|}
\hline ISL Type (Content) & $\begin{array}{l}\text { Observed } \\
\mathrm{N}\end{array}$ & $\begin{array}{l}\text { Expected } \\
\mathrm{N}\end{array}$ & Residual \\
\hline Experiment & 3 & 4.8 & -1.8 \\
\hline $\begin{array}{l}\text { Show or } \\
\text { demonstration }\end{array}$ & 2 & 4.8 & -2.8 \\
\hline Hands-on exhibits & 2 & 4.8 & -2.8 \\
\hline Field trips & 5 & 4.8 & .2 \\
\hline Science events & 6 & 4.8 & 1.2 \\
\hline Others & 11 & 4.8 & 6.2 \\
\hline Total & 29 & & \\
\hline
\end{tabular}

\begin{tabular}{|l|l|}
\hline & $\begin{array}{l}\text { ISL Type } \\
\text { (Content) }\end{array}$ \\
\hline $\begin{array}{l}\text { Chi- } \\
\text { Square }\end{array}$ & $12.172^{\mathrm{a}}$ \\
\hline $\mathrm{df}$ & 5 \\
\hline $\begin{array}{l}\text { Asymp. } \\
\text { Sig. }\end{array}$ & .033 \\
\hline $\begin{array}{l}\text { a. } 6 \text { cells } \\
\text { expected frequencies less } \\
\text { than 5. The minimum } \\
\text { expected cell frequency is } \\
4.8\end{array}$ \\
\hline
\end{tabular}

Table 14 ISL Type (Style)

\begin{tabular}{|l|l|l|l|}
\hline ISL Type (Style) & $\begin{array}{l}\text { Observed } \\
\mathrm{N}\end{array}$ & $\begin{array}{l}\text { Expected } \\
\mathrm{N}\end{array}$ & Residual \\
\hline Institutional Portal & 14 & 7.2 & 6.8 \\
\hline social interaction & 7 & 7.2 & -.2 \\
\hline text-based & 2 & 7.2 & -5.2 \\
\hline $\begin{array}{l}\text { All (Institutional } \\
\text { Portal) }\end{array}$ & 3 & 7.2 & -4.2 \\
\hline Institutional Portal & 10 & 7.2 & 2.8 \\
\hline Total & 36 & & \\
\hline
\end{tabular}

\begin{tabular}{|l|l|}
\hline & $\begin{array}{l}\text { ISL Type } \\
\text { (Style) }\end{array}$ \\
\hline $\begin{array}{l}\text { Chi- } \\
\text { Square }\end{array}$ & $13.722^{\mathrm{a}}$ \\
\hline df & 4 \\
\hline $\begin{array}{l}\text { Asymp. } \\
\text { Sig. }\end{array}$ & .008 \\
\hline $\begin{array}{l}\text { a. } 0 \text { cells } \quad(0.0 \%) \text { have } \\
\text { expected frequencies less } \\
\text { than 5. The minimum } \\
\text { expected cell frequency is } \\
7.2 \text {. }\end{array}$ \\
\hline
\end{tabular}

The 'Research Design' indicator was Chi-Square $=23.333$ and $\rho=.001$ [Table 15], and it can be confirmed that the observed values are statistically significant.

Table 15 Research Designs

\begin{tabular}{|l|l|l|l|}
\hline Research Designs & $\begin{array}{l}\text { Observed } \\
\mathrm{N}\end{array}$ & $\begin{array}{l}\text { Expected } \\
\mathrm{N}\end{array}$ & Residual \\
\hline Surveys & 16 & 6.8 & 9.3 \\
\hline Assessments/Tests & 2 & 6.8 & -4.8 \\
\hline Interviews & 12 & 6.8 & 5.3 \\
\hline Focus groups & 4 & 6.8 & -2.8 \\
\hline Observation & 5 & 6.8 & -1.8 \\
\hline Document Review & 5 & 6.8 & -1.8 \\
\hline $\begin{array}{l}\text { Participation } \\
\text { (Workshop, etc) }\end{array}$ & 4 & 6.8 & -2.8 \\
\hline Others & 6 & 6.8 & -.8 \\
\hline Total & 54 & & \\
\hline
\end{tabular}

\begin{tabular}{|l|l|}
\hline & $\begin{array}{l}\text { Research } \\
\text { Designs }\end{array}$ \\
\hline $\begin{array}{l}\text { Chi- } \\
\text { Square }\end{array}$ & $23.333^{\mathrm{a}}$ \\
\hline $\mathrm{df}$ & 7 \\
\hline $\begin{array}{l}\text { Asymp. } \\
\text { Sig. }\end{array}$ & .001 \\
\hline $\begin{array}{l}\text { a. } 0 \text { cells }(0.0 \%) \text { have } \\
\text { expected frequencies less } \\
\text { than 5. The minimum } \\
\text { expected cell frequency is } \\
6.8\end{array}$ \\
\hline
\end{tabular}

\section{Conclusions}


Although various studies on ISL are being implemented, there is a lack of trend analysis on studies related to ISL. This study was able to arrive at a few conclusions by analyzing relevant papers published within a specific time period. Firstly, most research works tended towards 'Empirical research articles' and 'Position papers'. Since there is a significant lack of research in 'Theoretical paper' category that suggests a new theory or theoretical framework, there apparently needs to be more research on this area.

Studies on ISL also mostly focused on information related to theoretical consideration, advice, recommendation and data development. Judging from the fact that there is a deficit in research on the 'Experiment' and 'Hands-on-exhibits' categories for the 'content' aspect, it is believed that there is a significant lack of research on direct participation activities through which students or visitors can actually experiment and manipulate things. With regards to the 'style' aspect, there needs to be more research in the 'Social interaction' category. Although this category was designed to examine participation for Friends, Experts, Family, Colleagues, Seminars and Conferences, it suffers from a lack of relevant studies.

Notably, it is difficult to find any trend analysis papers dealing with ISL that are based on performance indicators. The characteristics of ISL are such that performance evaluation on non-cognitive information is difficult, while ISL also has a variety of criteria with which to measure. Focusing on 'GLO' indicators, we also analyzed the kind of outcomes shown by ISL, and the expectations under which it was being applied. In conclusion, it was found that researchers were using ISL in order to pursue 'Knowledge and Understanding' and 'Attitudes and Values', of the five performance indicators of 'GLO'. In contrast, they were found to have the least expectations for 'Skills' and 'Enjoyment, Inspiration and Creativity', suggesting the need for future improvement in this area. In particular, while there were studies in only the 'Enjoyment' aspect of the 'Enjoyment, Inspiration and Creativity' category, there were none in 'Creativity' and 'Inspiration' categories, which focus on innovative thinking and inspirational behaviors.

It is also worth noting that studies related to ISL are being conducted under the initiative of the United States and the United Kingdom. Although research data are being published in other different countries, there is a room for greater improvement. Upon analysis of the contents of all the sample papers, most researchers make a positive conclusion on the educational effects of ISL. Moreover, they argue that rather than implementing ISL independently, more research is needed so that it can be implemented in sync with the general educational curriculum. More future supplementary studies would be necessary in this regard.

Because this paper is based on limited sample research work, it is insufficient in shedding much light on ISL. It hopes to enlarge the boundaries of ISL to collect a larger sample and implement research in future studies. Through this study, it hopes to suggest a direction for program development and further research for various educational practitioners. Also, it expects to provide a good opportunity for institutions using ISL in the field, as well as teachers and future researchers.

\section{Acknowledgements}

This research was financially supported by Hansung University.

\section{References}

[1] Dewey, John. Experience and education. 1983 : http://www.schoolofeducators.com/wpcontent/uploads/2011/12/EXPERIENCE-EDUCATION-JOHN-DEWEY.pdf

[2] Resnick LB. The 1987 presidential address learning in school and out. Educational researcher. 1987 Dec;16(9):13-54.

[3] Eshach H. Bridging in-school and out-of-school learning: Formal, non-formal, and informal education. Journal of science education and technology. 2007 Apr 1;16(2):171-90.

[4] Coombs PH, Ahmed M. Attacking Rural Poverty: How Nonformal Education Can Help. A Research Report for the World Bank Prepared by the International Council for Educational Development.

[5] Scolari CA, Buckingham D, Pereira S, Moura P, Koskimaa R, Pérez Ó, Contreras R, Horst H, GuerreroPico M, Lugo N, Masanet MJ. Teens, media and collaborative cultures: exploiting teens' transmedia skills in the classroom.

[6] National Research Council. Surrounded by science: Learning science in informal environments. National Academies Press; 2010 Apr 3.

[7] Kim M, Dopico E. Science education through informal education. Cultural studies of science education. 2016 Jun 1;11(2):439-45.

[8] Hein G. Learning science in informal environments: People, places, and pursuits. Museums \& Social Issues. 2009 Apr 1;4(1):113-24. 
[9] Krishnamurthi A, Rennie LJ. Informal science learning and education: Definition and goals. Afterschool Alliance, Retrieved from. 2013.

[10] Hooper-Greenhill E, Dodd J, Moussouri T, Jones C, Pickford C, Herman C, Morrison M, Vincent J, Toon R. Measuring the outcomes and impact of learning in museums, archives and libraries: the Learning Impact Research Project end of project paper.

[11] Gibbs K, Sani M, Thompson J. Lifelong learning in museums: a European handbook. Edisai; 2007.

[12] Smith MC, Locke SG, Boisse SJ, Gallagher PA, Krengel LE, Kuczek JE, McFarland JE, Rapoo B, Wertheim C. Productivity of educational psychologists in educational psychology journals, 19911996. Contemporary Educational Psychology. 1998 Apr 1;23(2):173-81.

[13] Tsai CC, Lydia Wen M. Research and trends in science education from 1998 to 2002: A content analysis of publication in selected journals. International journal of science education. 2005 Jan $1 ; 27(1): 3-14$.

[14] Triyarat W. Factors affecting engagement with informal science learning in Thailand: A regional perspective (Doctoral dissertation).

[15] Walsh L, Straits W. Informal science learning in the formal classroom. Science and Children. 2014 Jul 1;51(9):54.

[16] Crane V. Informal science learning: What the research says about television, science museums, and community-based projects. Research Communications, Limited; 1994.

[17] Rulf Fountain A, Levy AJ. NASA Informal Education: Final Report. A Descriptive Analysis of NASA's Informal Education Portfolio: Preliminary Case Studies. Abt Associates. 2010 Dec 28.

[18] Creswell JW, Creswell JD. Research design: Qualitative, quantitative, and mixed methods approaches. Sage publications; 2017 Nov 27.

[19] Hooper-Greenhill E. Museums and education: Purpose, pedagogy, performance. Routledge; 2007 Dec 12.

[20] Bollo A. Measuring museum impacts (Report 3). Emilia-Romagna: The Learning Museum Network Project. 2013.

[21] Hromek R, Roffey S. Promoting Social and Emotional Learning With Games: "It's Fun and We Learn Things". Simulation \& Gaming. 2009 Oct;40(5):626-44.

[22] Kim S, Hong KC. Design and Development of Software Model Textbooks with Novel Engineering for After-Schools. INTERNATIONAL JOURNAL OF EMERGING MULTIDISCIPLINARY RESEARCH (IJEMR). 2018 Dec 31;2(4):17-22.

[23] Bhoi, A. K., Sherpa, K. S., \& Khandelwal, B. (2018). Arrhythmia and ischemia classification and clustering using QRS-ST-T (QT) analysis of electrocardiogram. Cluster Computing, 21(1), 1033-1044.

[24] Reddy, A. V., Krishna, C. P., \& Mallick, P. K. (2019). An image classification framework exploring the capabilities of extreme learning machines and artificial bee colony. Neural Computing and Applications, 1-21.

[25] Bisoy, S. K., Mallick, P. K., \& Mishra, A. Fairness Analysis of TCP Variants in Asymmetric Network. International Journal of Engineering \& Technology, 7(2.12), 231-233.

[26] Mallick, P. K., Mishra, D., Patnaik, S., \& Shaw, K. (2016). A semi-supervised rough set and random forest approach for pattern classification of gene expression data. International Journal of Reasoningbased Intelligent Systems, 8(3-4), 155-167.

[27] Mallick, P. K., Mohanty, B. P., \& Jha, S. A novel approach using. Supervised and Unsupervised Learning" to prevent the adequacy of Intrusion Detection Systems", International Journal of Engineering \& Technology, 7(3.34), 474-479.

[28] Satapathy, S. K., Mishra, S., Sundeep, R. S., Teja, U. S. R., Mallick, P. K., Shruti, M., \& Shravya, K. (2019). Deep learning based image recognition for vehicle number information. International Journal of Innovative Technology and Exploring Engineering, 8, 52-55.

[29] Mallick, P. K., Kar, S. K., Mohanty, M. N., \& Kumar, S. S. (2015). Use of histogram approach in color band detection for electrical passive component. International Journal of Applied Engineering Research, 10(44), 31446-31450.

[30] Mishra, S., Mallick, P. K., Tripathy, H. K., Bhoi, A. K., \& González-Briones, A. (2020). Performance Evaluation of a Proposed Machine Learning Model for Chronic Disease Datasets Using an Integrated Attribute Evaluator and an Improved Decision Tree Classifier. Applied Sciences, 10(22), 8137.

[31] Bhoi, A. K., Sherpa, K. S., \& Mallick, P. K. (2014, April). A comparative analysis of neuropathic and healthy EMG signal using PSD. In 2014 International Conference on Communication and Signal Processing (pp. 1375-1379). IEEE.

[32] Bhoi, A. K., Sherpa, K. S., Khandelwal, B., \& Mallick, P. K. (2019). T Wave Analysis: Potential Marker of Arrhythmia and Ischemia Detection-A Review. In Cognitive Informatics and Soft Computing (pp. 121-130). Springer, Singapore. 
[33] Mishra, S., Mallick, P. K., Jena, L., \& Chae, G. S. (2020). Optimization of Skewed Data Using Sampling-Based Preprocessing Approach. Frontiers in Public Health, 8.

[34] Bhoi, A. K., \& Sherpa, K. S. (2016). Statistical analysis of QRS-complex to evaluate the QR versus RS interval alteration during ischemia. Journal of Medical Imaging and Health Informatics, 6(1), 210214.

[35] Mishra, S., Tripathy, H. K., Mallick, P. K., Bhoi, A. K., \& Barsocchi, P. (2020). EAGA-MLP-An Enhanced and Adaptive Hybrid Classification Model for Diabetes Diagnosis. Sensors, 20(14), 4036.

[36] Bhoi, A. K., Mallick, P. K., Liu, C. M., \& Balas, V. E (Eds.) (2021). Bio-inspired Neurocomputing, Springer.

[37] Oniani, S., Marques, G., Barnovi, S., Pires, I. M., \& Bhoi, A. K. (2020). Artificial Intelligence for Internet of Things and Enhanced Medical Systems. In Bio-inspired Neurocomputing (pp. 43-59). Springer, Singapore.

[38] Marques, G., Bhoi, A.K., Albuquerque, V.H.C. de, K.S., H. (Eds.) (2021). IoT in Healthcare and Ambient Assisted Living, Springer

[39] Marques, G., Miranda, N., Kumar Bhoi, A., Garcia-Zapirain, B., Hamrioui, S., \& de la Torre Díez, I. (2020). Internet of Things and Enhanced Living Environments: Measuring and Mapping Air Quality Using Cyber-physical Systems and Mobile Computing Technologies. Sensors, 20(3), 720. 
